\title{
THE DEVELOPMENT OF A METHOD FOR STUDYING GOAL SETTING IN PSYCHOTHERAPY
}

\author{
N.V. KISELNIKOVA (VOLKOVA) ${ }^{\mathrm{a}}$, V.F. SPIRIDONOV ${ }^{\mathrm{b}}$, E.V. LAVROVA ${ }^{\mathrm{a}}$, \\ E.A. KUMINSKAYA ${ }^{\text {a }}$, S.V. MARKOVA ${ }^{\mathrm{a}}$, M.M. DANINA ${ }^{\mathrm{a}}$
}

\begin{abstract}
${ }^{a}$ FBSSI Psychological Institute of the Russian Academy of Education, 9, Bld 4, Mokhovaya Str., Moscow, 125009, Russian Federation

${ }^{b}$ Russian Presidential Academy of National Economy and Public Administration (The Presidential Academy, RANEPA), 82-84, Prospect Vernadskogo, Moscow, 119571, Russian Federation
\end{abstract}

\begin{abstract}
The purpose of the study was to develop a method to assess the different characteristics of goal setting among psychotherapists with varying professional experience, and also to trace the relationship between the parameters of goal setting and the effectiveness of psychotherapy. To do this, a productive methodological basis can be a procedure for the study of professional thinking used in the psychology of expertise. The authors identified the characteristics and conditions of goal setting that contribute to the better achievement of goals. The basis for the development of the method was an assumption that the analysis of someone else's psychotherapeutic session from an expert position should stimulate the specialist's ideas about the standard goal setting process. The authors developed a grid of categories for the analysis of structured interview records. Studies using the developed procedure can be carried out in the following areas: 1) identifying the characteristics of goals that are more or less effective in the context of therapy outcomes; 2) studying the transformation of a goal setting process in connection with building up the professional experience of a psychotherapist; 3 ) revealing the peculiarity of the representation of a client's problem by psychotherapists with varying degrees of expertise; 4) studying the features of goal-setting and the representation of a client's problem by psychotherapists of different approaches. The approbation of this methodology for studying goal setting among therapists with more than 10 years of experience allowed us to identify the main characteristics of the problem and target state descriptions that correlate with the effective achievement of psychotherapeutic results, according to other research.
\end{abstract}

Keywords: goal setting, psychotherapy, counselling psychology, research methods.

\section{Introduction}

The goal is seen as a "representation of a result", and a person strives to reach that result (Leontiev, 2008). The goal is an indispensable element of any activity. The goal carries out different functions: motivation, guidance and regulation. The activity on building a goal and thinking about the image of a desired future is denoted by the concept, "goal setting".

In the field of counseling psychology, goal setting serves as a focus for therapeutic work, a criterion for evaluating progress and a common narrative, which can 
help clarify the relationship between the client and the therapist (Jansson, 2015). There are several empirical studies showing the relationship between some characteristics of goal setting and the effectiveness of counseling (Brace, 1992; Berking, Holtforth, Jacobi, \& Kröner-Herwig, 2005; Wollburg \& Braukhaus, 2010).

Goal setting activity in the dialogue between the client and the psychotherapist working together on the purpose of psychotherapy is the basis for forming a therapeutic alliance. A meta-analysis showed a significant relationship between alignment of goals, joint achievement of goals and treatment outcomes (Tryon \& Winograd, 2011). There is also evidence that active joint goal setting in psychotherapy increases the client's satisfaction with their therapeutic experience, as well as the perceived autonomy and control over the therapeutic process (Holliday, Ballinger, \& Playford, 2007; Doig, Fleming, Cornwell, \& Kuipers, 2009).

With all the diversity of research in the field of goal setting in psychotherapy, we note quite a few works where the phenomenology of goal setting would be described in more detail and its mechanisms in psychotherapy were discussed. Also, there are no procedures and methods for studying goal setting in psychotherapy and counseling from the position of a counselor, not a client, including studying the professionalization of goal setting (changing goal setting with the acquisition of professional experience). Thus, studying goal setting is meaningful from several points of view 1) the development of professional thinking 2) goal setting as a condition for the effectiveness of activity, 3 ) goal setting in conditions of solving problems together (by both the client and the counselor).

The purpose of the study was to develop and test a method to assess the difference in characteristics of goal setting by psychotherapists with different professional experience, and also to trace the relationship between the parameters of goal setting and the effectiveness of psychotherapy.

\section{Studying Goal Setting in Theory and Practice of Problem Solving}

Goal setting is the first stage in solving a problem that involves setting the main goal or a set of goals. Goal setting is an important subject in cognitive psychology, especially in the psychology of problem solving. Numerous studies show that the efficiency of the activity and the effectiveness of achieving goals depend on the characteristics of goal setting (Bandura \& Schunk, 1981; Zimmerman \& Kitsantas, 2002; Locke \& Latham, 2002, 2006). Usually the solving of complex problems involves distinguishing and managing different types of goals: global and specific, simple and multiple, main and intermediate (Dörner, 1997).

R.G. Sternberg (2003) provides evidence that the goal setting of students is closely related to the main sources of self-motivation. A. Bandura and D.H. Schunk (1981) studied the effect of setting short-term goals while solving mathematical problems on the students' self-efficacy and their interest in solving these problems. A number of patterns were revealed. The sample was divided into three groups. The first group had the immediate goal of completing one set of tasks during each session. The second group was given a distant goal, to complete the solution of all sets by the end of all sessions. The third group was given a global goal, to work productively. 
The immediate goals increased perseverance during problem solving and led to the highest level of solving mathematical problems and self-efficacy when checking on an additional test. The immediate goals also increased the students' freedom of choice when working on mathematical problems, which is a measure of intrinsic interest in this task. These results show how immediate goal setting can increase not only the quality and intensity of the task-solving process, but also self-efficacy.

Researchers also studied hierarchical links between goals in solving problem. One of these links is related to procedural and effective goals. Procedural goals are focused on strategies for solving problems, while effective goals are focused on the final product (a solution). B.J. Zimmerman, A. Kitsantas (2002) studied how high school students solved verbal problems that included combining and generalizing sentences. The researchers identified cyclical links between goal setting, task performance, self-satisfaction, self-efficacy and internal interest.

E.A. Locke, G.P. Latham $(2002,2006)$ studied the relationship between goal setting and performance in the Goal-Setting Theory, and distinguished four patterns:

1) Setting difficult goals causes more persistence and effort than setting simple and average goals or setting blurry unclear goals.

2) The setting of goals directs attention and effort to actions that are relevant to the goals.

3) The result of achieving goals depends on knowledge and skills. At the same time, goals can both stimulate the use of actual knowledge and skills, bring the necessary knowledge not previously used to the level of awareness, and also activate the search for new knowledge and skills, especially when solving new complex problems.

4) The setting of goals is mediated by different variables: personal traits, confidence in knowledge in specific domains (Bandura, 1993), autonomy, etc.

E.A. Locke, G.P. Latham $(2002,2006)$ studied the influence of previous experience and self-efficacy on setting goals, the relationship between types of goals and the effectiveness of their achievement. It was shown that people who assess themselves as more effective set more difficult goals, demonstrate a more pronounced purposefulness and commitment to the goal seek and use more effective decision strategies. E.A. Locke, G.P. Latham $(2002,2006)$ also found out that goals aimed at learning, training or demonstrating the available knowledge and skills are associated with higher performance, in contrast to goals aimed at achieving concrete results. A goal aimed at achievement raises anxiety because of the situation of assessment. People tend to avoid situations where they can be judged as incompetent, and in this situation they choose easy tasks or refuse to do anything at all.

D.A. Kolb, R.E. Boyatzis (1970) conducted a study that identifies the characteristics of the goal setting process in relationship between these characteristics and the effectiveness of behavior aimed at change. After studying more than 1000 cases of self-change behaviors (based on self-analysis and objective behavioral records) they found that people achieve their goals more successfully, if:

1) The goals are well understood

2) A person has an expectation of success

3) There is a sufficient level of psychological safety

4) Tools are used to measure progress 
5) The subject of change has a sense of control over the process of change and the criteria for their evaluation.

Effective goal setting technologies have been developed and widely used in psychological practice. The SMART technology is the most famous (Doran, 1981). It describes the requirements that a 'good' goal must meet. These are: $\mathrm{S}$ - specific; $\mathrm{M}$ - measurable; A - achievable; $\mathrm{R}$ - result-oriented; $\mathrm{T}$ - timed.

If a goal is specific, it means that it is clear what actions to achieve the goal must be undertaken and how to evaluate the result. The measurability of a goal means that its formulation includes the parameters for tracking the achievement of the result. The goal achievability reflects the level of its complexity relative to the subject's resources of goal setting and objective conditions for achieving the goal. The orientation to the result means the formulation of the goal in terms of the result, not the process. For example, you can set a goal (the staff must come to work one hour earlier), but if you do not determine the result anticipated from such an action, then an extra hour can be spent in drinking coffee and talking with colleagues. Correspondence to a certain period of the achievement implies the implementation of the goal in a specific period of time. If there is no time frame, in which goal should be achieved, then the achievement of that goal will be constantly postponed.

Thus, there are several characteristics and conditions of goals that contribute to high levels of achievement. Such characteristics include a) short-term setting (intermediate goals), b) a focus on the process or an outcome (for different types of activity), c) awareness, d) feedback and tools for assessing the progress, e) self-efficacy. Now we will consider whether this data is reflected in studies of the psychotherapeutic process as a practice aimed at achieving the client's goals for self-change.

\section{Goal Setting in Psychological Counseling and Psychotherapy}

Cognitive psychology studies the goal setting process on the basis of problems solved by one subject. But the consultative and psychotherapeutic process is a joint solution of the client's problem through dialogue with a specialist.

Psychotherapy can be seen as a means of achieving the goals agreed on by the patient and the therapist. In this case, achieving the goal can be considered a significant measure of success in psychotherapy (Berking et al., 2005). In addition, the achievement of a goal relates to other indicators of success in therapy, whereas frequent changes in the goals of the work related to the lack of achievement of the goals lead to poor results. In psychotherapy the analysis of goals occurs in the space of complaint (what the client does not like), the request (what he/she wants to receive as a result of work), and the contract (the joint formulation of the goal of work that takes into account the client's request and the therapist's capabilities). A number of consultative schools use special techniques to transform the client's request into a contract. This is necessary because goals that clients offer for therapy can be vague, unrealistic or unable to help effectively in the long term.

K. Brace (1992) considers two principles that can be universally applied in psychotherapy and counseling: respect for the well-being of clients and their selfdetermination. The discussion and application of these principles leads to the 
formulation of a set of recommendations in order to assist therapists and consultants in selecting tools and ultimate goals. It is assumed that these recommendations can be applied regardless of specific personal and cultural values of the therapist and the client.

The values of both the client and the therapist affect the goal setting in the therapy process. Because of this, there is a danger that the goals and goal setting in psychotherapy can be arbitrary, that is, they can simply reflect the value preferences of specific therapists or clients.

$\mathrm{K}$. Brace offers a means by which therapists can determine whether a goal is universal in terms of ethical standards, even if it does not match the personal values of a therapist.

The respect for self-determination of clients is also necessary in psychotherapy, because therapy provides an opportunity for clients to make the changes they want in their lives. The therapist's views may often differ from the client's views on what thoughts and actions will contribute to the client's desired changes, and the therapist can influence the way the client accepts methods of change that the client would not choose on their own. If the therapist assumes that what the client wants is not really useful for him/her, the therapist can also influence the change in their clients' desires. However, the client's self-determination in psychotherapy is mandatory, because the purpose of therapy is to achieve the client's goals.

The formulated goals should be checked by both the client and the therapist. It is necessary to determine whether the goals are formulated for the benefit of the client. In the case when the goals that are defined by the client are mutually incompatible, the therapist should point to this and allow the client to formulate consistent goals.

Changes that clients receive as therapy outcomes can affect their immediate surroundings (their family, friends or colleagues). The principle of respect for people implies that it is the therapist's responsibility to consider the client's environment in goal setting and working with goals.

These principles set a general framework for goal setting in counseling and therapy, rather than specific indications of which types of goals are desirable and acceptable.

M. Berking et al. (2005) argue that attainability is one of the most important among the characteristics of goals. Without it therapy becomes a waste of time, energy and money, and further reduces the client's self-efficacy. Sometimes it may be useful to work on goals that can be achieved in a short time and with little energy costs for the client (for example, at the beginning of therapy or in cases where there is a danger of threatening the therapeutic relationship). Working on relatively simple goals can help clients create confidence in the possibility of change and strengthen the therapeutic union.

The formulation of the client's request and the therapist's response to it is one of the most important tasks of the first consultation. Often the client makes an unrealistic request as to the goals he/she would like to achieve in the process of psychotherapy. That is why many authors believe that it is much more productive when the therapist themselves formulates a working request without expecting it from the client. This is due to the fact that the majority of clients have no idea of what opportunities exist in psychotherapy, they are not aware of the types of therapy and do not know exactly how a psychotherapist can help. 
S. Cormier, H. Hackney (2015) consider the client as a person who is constantly experiencing needs. However, the client does not always perceive and recognize their needs. The client seeks the consultant's help when unsatisfied needs become a problem. The authors believe that the role of the counselor psychologist is to recognize the client's unsatisfied needs. After that, the consultant should help the client to transform the identified needs and desires. It is important for switching the client from a passive position to an active one. It is necessary to help the client to formulate goals that satisfy their needs and show the client that some progress is coming after the consultant finds out what solutions the client has already tried to achieve.

Process tasks and goals are associated with the specifying therapeutic conditions necessary for a client's change. Process tasks are universal for all clients. They include common tasks, such as establishing contact, creating safe conditions, expressing empathy and acceptance. The procedural goals are individual for each client. They are directly related to the changes that should occur as a result of counseling.

Goal setting is a flexible process that allows regular updates. In the process of consultation the client and the counselor can change goals formulated at the first sessions. It is important that there are joint goals. This means that both the client and the consultant agree to work towards achieving the set goals.

According to the authors, there are three elements in a "good goal":

1. The goal includes the behavior that needs to be changed, the conditions and the degree of change;

2. A description of the conditions necessary to achieve the desired behavior;

3. The goal includes relevant and realistic levels of new behavior. It is important to set achievable goals and achieve global goals by a successive approximation.

The consultant should involve the client in goal setting, otherwise the process of therapy is almost impossible.

There is a number of studies that verify the theoretical considerations described above. L. LaFerriere, R. Calsyn (1978) evaluated the effectiveness of psychotherapy. The evaluation depended on the method of clients' goals setting. In the experimental group, the participants formulated goals together with the therapist using the Goal Attainment Scale (GAS). Clients from the control group set their own treatment goals.

The psychotherapeutic sessions were conducted with clients using behavioral and psychodynamic approaches. Before and after six psychotherapeutic sessions, the clients were evaluated for anxiety, depression, self-esteem. In addition, clients and specialists gave feedback about satisfaction with the consultations, the motivation for change, the assessment of change and the awareness of specific therapeutic goals. The data showed that despite the similar satisfaction demonstrated by the clients of both the experimental and control groups, people who formulated the goals together with the psychotherapist showed the best indicators of the psychological status at the output. They showed a decrease in anxiety, , increased self-esteem, higher rates of changes in therapy and motivation for change, as well as the awareness of goals.

E. Wollburg, C. Braukhaus (2010) studied how the type of goal formulation affects the psychotherapy outcomes in depressed patients. The study involved 6,570 people as participants, who had undergone a course of cognitive-behavioral, or multimodal psychotherapy and drug therapy for seven weeks. 
At the beginning of the study scientists asked all patients to formulate at least three goals. Also, all participants of the study were administered the Depression Scale of A. Beck and had a clinical evaluation to assess the severity of depressive symptoms. Two experts classified the goals into groups of achievement and avoidance. At the end of the therapy the patients were re-evaluated and scaled by the degree of goal attainment.

It was shown that the degree of severity of depressive symptoms did not correlate with the number of avoidance goals. But they found a connection with the average rating of achievement goals. This suggests that the nature of goals formulation can be an indicator of the effectiveness of psychotherapy.

Thus, we see that many consultative psychologists agree that formulated goals must be achievable and realistic but there are disputes over the degree of the therapist's activity in goal setting. Some authors believe that the therapist should follow the goal setting for the client counting on their self-determination processes. Others believe that the specialist should have the decisive vote. At the same time, empirical data indicates the productivity of a joint, dialogic goal setting.

\section{Goal Setting in Various Approaches to Psychological Counseling}

Psychotherapeutic approaches can be classified as effective (focusing mainly on the problem and/or its solution), or procedural (focusing on the procedural aspects of the interaction with the client) by reason of setting goals.

For the first approach, the basis for the therapeutic strategy choice is the client's problem itself. That involves the client's problem representation building. An important phase in this process is mutual goal setting with the client. The client's problem transformation starts at this point.

The second, process-oriented, approach is focused on developing special therapeutic relationships that contribute to personal growth in certain conditions. In this case goals are achieved as a result of these conditions (Nelson-Jones, 2000).

We consider Solution-Focused Brief Therapy and Person-Centered Therapy examples of these two approaches reflecting polar positions to goal setting in psychotherapy.

A psychotherapist working in a solution-focused approach contributes to the client's change through talking about decisions. He/she provides change suggesting that the clients should imagine their future without problems and make the appropriate changes. The client achieves their desired future in small steps using their resources and strengths with the therapist's help. Short-term methods prevail in this approach, and the aim is to change a specific, observable behavior.

Therapists working in a solution-focused approach downplay the role of past experience in favor of behavior changes that help to achieve one's goals. Effective goals here should be specific, small, positively formulated and important for the client. Properly constructed goals should be described as the presence of something positive, not the absence of something negative.

In person-centered approach, the practitioner does not lead or push the client to a specific decision, and the therapeutic goal is not easily measurable. It is 
assumed that certain conditions created by a psychotherapist (emotional contact, congruence, unconditional positive acceptance, empathic listening), help the client to accept himself or herself, and that causes the desired changes. Person-centered therapy assumes the therapist's refusal from the expert position. The goals are not discussed in the terms of an expected result and, moreover, are not formatted by the therapist for certain properties.

K.V. Yagnyuk et al. (2013) showed differences in goal setting in other approaches: the brief dynamic therapy and the psychoanalytic approach. The brief dynamic therapists usually focus on specific present and future goals of a client. Goals set by psychoanalytic therapists refer more to past events and experiences.

Summarizing the data in goal setting strategies in various areas of counseling and therapy, it can be stated that the main discrepancies are: the specificity/globality of a goal, the presence/absence of the specialist's activity in goal setting, facilitating this activity, understanding the target of the work (past/present, changes in inner experience/behavior, etc.). A common area for different approaches is the focus on clients' interests and needs in goal setting process.

\section{The Psychotherapeutic Contract as a Framework for Setting Goals in Psychological Counseling and Psychotherapy}

Psychotherapeutic and counseling practice usually starts with agreeing to a psychotherapeutic contract that contains three main aspects. First is the general view on the client's need for psychotherapy and taking part in it. Second is the approval of goals and procedures necessary to achieve these goals, as well as the criteria by which they can be judged.

The psychotherapeutic goal agreement is achieved by comparing the client's needs and the therapist's professional capabilities. Finally, it includes organizational issues, such as time, place, frequency of sessions and payment.

It should be emphasized that not in all schools and approaches a contract implies that the purpose has been clearly established. However, when this happens, as a rule, not only goals alone, but also procedures aimed at achieving the goals are approved.

The provisions of a psychotherapeutic contract are discussed in detail, even if they seem obvious or not worthy of attention, in order to avoid misunderstanding at subsequent phases of psychotherapy. It was proved that the goal congruence between the therapist and the client affects the "strength of the therapeutic alliance" that strongly affects the therapeutic results.

The concept of contract in psychotherapy was first used in transactional analysis (Berne, 1961). The contract there was a pronounced mutual commitment to a strictly defined plan of action. From the very first sessions the client entered into a "change contract" with the therapist, in which goals and ways of achieving them were determined.

The study of J.R. Long (2001) confirms the unique role of the therapeutic contract. He explains that the conclusion of a therapeutic contract is an intervention itself. Clients usually know more about their problem state than about the desired state. In J.R. Long's study of the psychotherapist's and client's agreement of the goals, negative 
therapy outcomes were associated with the absence of an explicit therapeutic contract. Based on this data, it was concluded that it is extremely important for psychotherapists to reach a goal agreement with clients as a form of intervention.

This agreement may include the goal itself, as well as an explanation of its causes. The available results show that an intuitive consensus about the goal alone is not enough. While the client and the therapist may think that they are equally perceiving the goal, in an actual situation their goals may be incompatible. Therefore, it is advisable to conclude a goal agreement explicitly at the first session.

It is also important for a therapist to understand that during a diagnostic conversation the client's view on their problems, goals and themselves may change. Therefore, after the first session the therapist should clarify with the client how he/she understands the purpose of psychotherapy, in order not to start working on irrelevant goals. Well-defined goals help monitor the course of psychotherapy and determine its completion. Otherwise, it is impossible to understand what stage of the progress the client is at (Weiner, 2002).

The importance of agreeing goals is also shown by G.S. Tryon, G. Winograd (2011). The authors define the agreement as follows: (a) goal agreement between the client and the therapist; (b) the way in which the therapist explains the nature of therapy and its expected results, and the client's understanding of this information; (c) the degree to which the goal is agreed upon, and the client's belief that the goals are clearly defined; (d) the client's focus on goals; (e) the consistency of the client's and the therapist's views on the origin of the problem and on one's responsibility for solving the problem.

The results of the meta-analysis carried out in the study indicate strong relationships between the goal agreement, the client's and the therapist's cooperation and positive outcomes of therapy. The results point to a number of conclusions that can be used to improve the effectiveness of psychotherapists and counselors:

1. The work on client's problems should start only after an agreement on the goals and the ways necessary for their achievement has been reached by the client and the psychotherapist.

2. The therapist shouldn't immediately put forward his/her vision of the goals and solutions of the problem. First they need to listen to what the client says, and then adjust the work in accordance with that information and their understanding.

3. The therapist should encourage the client's contribution to psychotherapy by listening to their feedback, understanding, reflecting and clarifying, collecting information on current progress, motivating for change, supporting and providing feedback on their progress.

4. It is necessary to tell clients about the importance of their joint contribution to the success of therapy.

5. It is important to encourage homework. The therapist should assign tasks appropriate to goals, starting with simple ones.

6 . The therapist should regularly coordinate the psychotherapeutic work with his/her clients, to ensure that there is a mutual understanding.

7. It may be necessary to change the goals and methods of therapy in response to the feedback. 


\section{Developing a Method for Studying Goal Setting in Psychotherapy}

The statements listed above lead to a number of research questions:

1. What are the characteristics of the goal setting process in psychological counseling and psychotherapy?

2. Which goal characteristics are more or less effective in the context of the counseling outcome?

3. Do the process of a goal setting and the characteristics of a goal transform along with the building up the professional experience of a psychotherapist?

These questions became the starting point for the development of a tool that enables the evaluation of the goal setting process and the characteristics of a psychotherapeutic goal in the following parameters:

a) the way a goal is set up (independently by the therapist or the client/in dialogue)

b) the characteristics of a goal (concreteness, positivity, attainability, formulation, etc.)

c) the type of a goal (main, intermediate, secondary).

Different methods of goal setting are described in the studies of $\mathrm{K}$. Brace (1992), S. Cormier, H. Hackney (2015), L. LaFerriere, R. Calsyn (1978). Based on these studies, we assume that the most effective way of setting goals is through dialogue. The client is the bearer of knowledge about their own needs, and the therapist is the bearer of knowledge about the rules for setting the goals and identifying the client's needs.

Goal characteristics were initially partially taken from psychotherapeutic literature (the criteria of the psychotherapeutic contract by S. Cormier, H. Hackney (2015), M. Berking et al. (2005)), and partially from the psychology of problem solving studies (Dörner, 1997) and the SMART technology (Doran, 1981).

Types of goals were described by D. Dörner (1997) on the basis of solving complex dynamic system problems that include the process of solving psychological problems. Later, the categories were refined and transformed during interviews.

At the data collection stage we conducted individual structured interviews on the fragment of a psychotherapeutic session (see the questions in the Appendix). The procedure of our research is based on methodological principles of psychology of expertise, specifically, on that part of it that deals with the study of expert thinking (Chase \& Simon, 1973; Claessen \& Boshuisen, 1985; Spiridonov, 2013; Kukushkina \& Spiridonov, 2008). It was shown in a number of studies that the differences between experts and novices relate not only to the effectiveness of solution and ways of organizing knowledge in memory, but also to ways of goal setting. Experts spend significantly more time preparing for decisions, planning their actions (especially at the early stages of decision-making), and finding out features of the current problem situation, making more "research" actions (Dörner, 1997).

These ideas were implemented through the following research procedure:

1. The participant fills in the questionnaires about their education, professional experience, preferred types of client problems and the methods and approaches they use (see Appendix). 
2. The participant reads the transcript of another psychotherapist's first meeting with a client. This transcript presented is a logically arranged fragment of communication between a therapist and a client. It includes the therapist's phrases related to setting the goal, its clarification and particular steps to achieve it, as well as the client's answers. Phrases from the full transcript of the session were selected by six experts in the field of problem solving and psychotherapy. The experts assessed the compliance of each phrase with a particular action to the goal setting or achieving the goal. Sixteen phrases of the therapist were selected with high degrees of consistency of expert assessments (some of them are presented in the Appendix). These remarks were analyzed by the respondents.

3. We conducted individual structured interviews that ranged from 50 to $70 \mathrm{~min}$. All interviews are tape-recorded and transcribed. The participants were asked to analyze and give comments to the presented case. In order to reveal the degree of similarity and differences in the characteristics of the analysis of the problem drawn from the expert and professional positions, the interview included questions that induced the respondent to express an opinion about the therapist's work on the case, and then describe their own way of achieving similar goals.

The data analysis method is content analysis on the grid of categories. The tables below show the categories, codes and sub codes for analysis and notes (the rationale for including each of them in the analysis).

This grid was developed during six iterations of sequential analysis of interviews and the correction of the coding table.

The form for preliminary content analysis of the respondents' statements made from an expert position in relation to the case, as well as from the respondent's own professional position, includes a) analysis of the initial (problem) state, b) analysis of the desired (target) state. According to A. Newell, G. Simon (1972), D. Dörner (1997), etc., the target state is part of the structure of the task and the problem. Its second component is the initial state. The transition between these two positions in the problem space is unknown to the solver and causes difficulties.

Statements reflecting the features of the goal setting procedure were also encoded: formulating a goal in a dialogue with the client, by therapist themselves, or accepting a goal in the client's wording. According to the studies of L. LaFerriere, R. Calsyn (1978), S. Cormier and H. Hackney (2015), etc., the goal setting method influences the effectiveness of psychotherapy, goal setting with the therapist is further associated with the best indicators of the client's psychological status. It is assumed that this category of analysis will allow us to establish differences between therapists not only with different work experience, but also between those practicing different approaches. Then the coding of semantic units was carried out according to Table 1:

Analysis of the results involves a frequency analysis of codes and a comparison of samples of psychotherapists in three main categories:

1) features of goals and their components;

2) the means of goal setting;

3) types of psychotherapeutic goals.

There are some versions of the presented method: for psychologists without practical work experience in the field of psychotherapy (including students), as 
well as for conducting research with writing in Russian and English. The English version was obtained by direct and reverse translation, and then it was checked by English native speakers and Russian-speaking therapists who are fluent in English and who practice in English.

Table 1

Problem Analysis

\begin{tabular}{|c|c|c|}
\hline \multicolumn{3}{|c|}{ 1.1. Problem state } \\
\hline Category & Codes & Notes \\
\hline $\begin{array}{l}\text { PS1 Components } \\
\text { of the problem } \\
\text { state }\end{array}$ & $\begin{array}{l}\text { PS1-1 Thoughts } \\
\text { PS1-2 Emotions } \\
\text { PS1-3 Behavior } \\
\text { PS1-4 Attitudes and } \\
\text { values } \\
\text { PS1-5 Others }\end{array}$ & $\begin{array}{l}\text { As elements of the client's problem, the manifesta- } \\
\text { tions of mental reality and behavior that are repre- } \\
\text { sented in the psychotherapeutic situation as the } \\
\text { subject of a complaint and simultaneously the } \\
\text { work of the client and the specialist are consid- } \\
\text { ered. }\end{array}$ \\
\hline $\begin{array}{l}\text { PS2 Types of } \\
\text { components of } \\
\text { the problem state }\end{array}$ & $\begin{array}{l}\text { PS2-1 Represented } \\
\text { by the client in an } \\
\text { explicit form } \\
\text { PS2-2 Latent } \\
\text { PS2-3 Manageable } \\
\text { PS2-4 Unmanageable } \\
\text { PS2-5 Others }\end{array}$ & $\begin{array}{l}\text { These types of elements of the problem situation } \\
\text { are identified in accordance with the work of R. } \\
\text { Ackoff (1978). Manageable elements are those } \\
\text { that a person (or people) making a decision can } \\
\text { manage. Unmanageable variables along with man- } \\
\text { ageable ones can influence the outcome of the } \\
\text { problem. It is important to keep in mind that } \\
\text { unmanageable variables do not always have the } \\
\text { features of unmanageability: they can be regulated } \\
\text { by other people or conditions. In a situation of } \\
\text { psychotherapy, the manageable variables include } \\
\text { elements of the psychic reality and behavior of the } \\
\text { client, unmanageable variables involve third par- } \\
\text { ties and external circumstances that cannot be the } \\
\text { subject of the therapist's work }\end{array}$ \\
\hline $\begin{array}{l}\text { PS3 } \\
\text { Distinguishing } \\
\text { the links between } \\
\text { components of } \\
\text { the problem state }\end{array}$ & $\begin{array}{l}\text { PS3-1 Distinguishing } \\
\text { current links } \\
\text { PS3-2 Distinguishing } \\
\text { causal links } \\
\text { PS3-3 Distinguishing } \\
\text { surface links }\end{array}$ & $\begin{array}{l}\text { According to the works of D. Dörner (1997), suc- } \\
\text { cessful 'solvers' differ from unsuccessful ones in } \\
\text { their ability to offer a variety of hypotheses about } \\
\text { the functioning of the problem, identify causal } \\
\text { relationships, rather than focusing solely on the } \\
\text { superficial symptomatology of the problem. }\end{array}$ \\
\hline $\begin{array}{l}\text { PS4 Fixing the } \\
\text { dynamics of com- } \\
\text { ponents and rela- } \\
\text { tions between } \\
\text { them }\end{array}$ & & $\begin{array}{l}\text { Another important factor of effective solutions is } \\
\text { the consideration of the remote and side effects of } \\
\text { influence, as well as an analysis of the trends in } \\
\text { the development of the problem, not the fixation } \\
\text { on the current moment (D. Dörner) }\end{array}$ \\
\hline
\end{tabular}

\section{Results}

A sample of the pilot study consisted of ten psychotherapists with work experience of more than 10 years (aged 41-56 years old), including one man and nine 
Table 1 (finishing)

\begin{tabular}{|c|c|c|}
\hline \multicolumn{3}{|c|}{ 1.2. Goal state } \\
\hline Category & Codes & Notes \\
\hline $\begin{array}{l}\text { GS1 } \\
\text { Features of } \\
\text { a goal }\end{array}$ & $\begin{array}{l}\text { GS1-1 Positive } \\
\text { GS1-2 Negative } \\
\text { GS1-3 There are no third parties } \\
\text { GS1-4 Specific (includes criteria for } \\
\text { achieving) } \\
\text { GS1-5 Global } \\
\text { GS1-6 Achieved by means of psy- } \\
\text { chotherapy: } \\
\text { GS1-6-1 Change in thoughts } \\
\text { GS1-6-2 Change in emotions } \\
\text { GS1-6-3 Behavioral change } \\
\text { GS1-6-4 Change in attitudes } \\
\text { GS1-7 Not achievable by means of } \\
\text { psychotherapy } \\
\text { GS1-8 Clear } \\
\text { GS1-9 Formulated with the use of } \\
\text { professional language } \\
\text { GS1-10 Duplicating the client's } \\
\text { words from the case } \\
\text { GS1-11 Using anti- and pseudo-sci- } \\
\text { entific concepts } \\
\text { GS1-12 A goal is not related to the } \\
\text { content of the client's case }\end{array}$ & $\begin{array}{l}\text { Characteristics of the goals were identi- } \\
\text { fied on the basis of data from the studies } \\
\text { of E. Wollburg, C. Braukhaus (2010), } \\
\text { D. Dörner (1997), and the works of Doran } \\
\text { (1981), A. Newell, G. Simon (Newell \& } \\
\text { Simon, 1972), J.J. Platt, G. Spivack } \\
\text { (1975). Each of the characteristics is asso- } \\
\text { ciated with a more or less effective prob- } \\
\text { lem solving, and its manifestation can act } \\
\text { as a criterion differentiating professionals } \\
\text { with different levels of expertise. }\end{array}$ \\
\hline $\begin{array}{l}\text { GS2 Way } \\
\text { of goal set- } \\
\text { ting }\end{array}$ & $\begin{array}{l}\text { GS2-1 In dialogue with the client } \\
\text { GS2-2 By the therapist themselves } \\
\text { GS2-3 Accepting the client's formu- } \\
\text { lation }\end{array}$ & See the note to Table 3. \\
\hline $\begin{array}{l}\text { GS3 Types } \\
\text { of goals }\end{array}$ & $\begin{array}{l}\text { GS3-1 Intermediate goals } \\
\text { GS3-2 Key goal } \\
\text { GS3-3 Side goal }\end{array}$ & $\begin{array}{l}\text { According to D. Dörner, the ability to } \\
\text { determine the center of the direction of } \\
\text { efforts, to identify central and peripheral } \\
\text { goals, and also to decompose the ultimate } \\
\text { goal into intermediate ones, is extremely } \\
\text { important for the effective problem solving. }\end{array}$ \\
\hline
\end{tabular}

women who voluntarily responded to invitations to take part in a study published in social networks.

According to results of the content analysis of the interviews using Friedman's two-factor rank analysis of variance for related samples, differences were found at significance levels of $p<.001$ between the codes in the PS2 category (types of problem state components, see Table 2 and Figure 1) and GS1 (target characteristics, see Table 3 and Figure 2):

We can see that when analyzing a client's problem, experienced therapists significantly more often point out the components of the problem that are explicitly 
Frequency of Codes PS2 (Types of Components of the Problem State)

\begin{tabular}{|c|l|c|}
\hline Codes & \multicolumn{1}{|c|}{ Name } & Frequency \\
\hline PS2.1 & $\begin{array}{l}\text { Types of components of the problem state: represented by the client } \\
\text { in an explicit form }\end{array}$ & 0.9 \\
\hline PS 2.2 & Types of components of the problem state: latent & 0.5 \\
\hline PS 2.3 & Types of components of the problem state: manageable & 0.1 \\
\hline PS 2.4 & Types of components of the problem state: unmanageable & 0.1 \\
\hline PS 2.5 & Types of components of the problem state: other & 0.0 \\
\hline
\end{tabular}

Table 3

Frequency of Codes GS1 (Features of a Goal)

\begin{tabular}{|c|l|c|}
\hline Codes & \multicolumn{1}{|c|}{ Name } & Frequency \\
\hline GS1.1 & Positive & 0.9 \\
\hline GS1.2 & Negative & 0.6 \\
\hline GS1.3 & There are no third parties & 1.5 \\
\hline GS1.4 & Specific (includes criteria for achieving) & 0.1 \\
\hline GS1.5 & Global & 0.7 \\
\hline GS1.6 & Achieved by means of psychotherapy & 1.5 \\
\hline GS1.7 & Not achievable by means of psychotherapy & 0 \\
\hline GS1.8 & Clear & 0.9 \\
\hline GS1.9 & Formulated using professional language & 0.6 \\
\hline GS1.10 & Duplicating client's words from the case & 0.1 \\
\hline
\end{tabular}

Figure 1

Confidence interval, category PS2

Figure 2
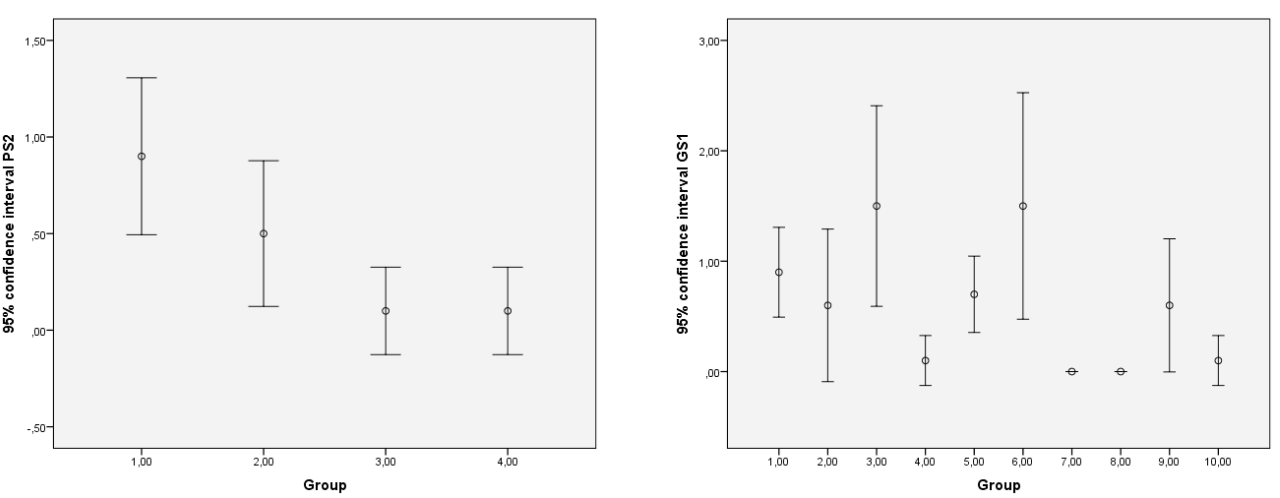
represented by the client and significantly less often, but equally mention both controllable (those that can be changed during therapy) and uncontrollable variables (those that are directly not included in the work of the therapist, for example, external circumstances). Also, when describing a target state, therapists significantly more often formulate attainable goals, that don't include third parties, clear and positive. It should be noted that all these goal variables, according to research, correlate with the effective achievement of positive results in therapy. Therefore, the analysis of the developed grid of categories and codes allows the construction of an individual's portrait of goal setting and highlighting the key features of goals and problems in the selected group of specialists.

The approbation of this procedure is currently being performed on four samples of Russian-speaking respondents: psychotherapists who have been practicing from 1 to 3 years, from 4 to 9 years and from 10 years and more, as well as undergraduate students without experience in training and practice in the field of psychotherapy. Also participating in our study are two samples of English-speaking therapists who have professional experience of up to 3 years and over 10 years.

\section{Conclusion}

The analysis of theoretical and empirical works on goal setting in the work of therapists allows us to highlight the following key points:

The authors systematized the goal setting characteristics that would contribute to the more efficient achievement of goals and satisfaction with the achieved results, from a variety of studies in different contexts of goal setting. These characteristics include: a) short-term (presence of intermediate goals), b) procedural-performance (different types of goals are recommended for different types of activities), c) awareness, d) availability of feedback and progress assessment tools, e) self-efficacy assessment in formulating goals. It is noted that there are no studies in which these characteristics have been investigated in the context of various approaches and methods of psychotherapy.

2. Methodological and educational materials on psychotherapy state that the reachability and realism of the goal of working with a client are essential to the effective work of a psychotherapist. There is also a confirmation of the effectiveness of joint, dialogic goal setting for improving the client's psychological status. However, studies of various characteristics of the process of goal setting in different psychotherapeutic conditions, as well as their influence on the results of psychotherapy, are limited.

3. Despite the fact that in different schools of therapy there are discrepancies in the parameters of goal specificity/globality, as well as the presence/absence of specially organized specialist's activities in formulating the goal and facilitating this activity with the client, and understanding the focus of work (past-present, changing the inner world/behaviors, etc.), there is a lack of data on how these parameters contribute to the real work of a psychotherapist, regardless of his/her therapeutic approach.

4. A number of researchers (for example, G.S. Tryon and G. Winograd, 2011) showed there is a link between the alignment of the client's and therapist's goals 
and positive results of therapy. On the basis of practical literature in the field of psychotherapy, we have identified procedures of goal setting in counseling, ways of achieving them, and criteria for evaluating their achievement within the framework of a psychotherapeutic contract.

5. Due to the insufficient study of the connection between the various characteristics of the goal setting process and the results of psychotherapy in various approaches, it is necessary to develop new research procedures to identify differences in goal setting in psychotherapy (characteristics of goals, methods and types used). Of particular interest is the approach for the transfer of the professional thinking research methodology in psychology of expertise and complex problemsolving to the psychotherapeutic context. This integration is considered by the authors for the first time in this scientific field.

6. Approbation of this methodology for studying the representation of the client's problem among therapists with more than 10 years of experience allowed us to identify the main characteristics of the problem and target state descriptions that correlate with the effective achievement of psychotherapeutic results, according to research. The prospect of the study is to compare the features of goal setting and problem analysis among therapists with different work experience and therapeutic approaches.

\section{References}

Ackoff, R. (1978). The art of problem solving. New York: John Wiley and Sons.

Bandura, A. (1993). Perceived self-efficacy in cognitive development and functioning. Educational Psychologist, 28(2), 117-148.

Bandura, A., \& Schunk, D. H. (1981). Cultivating competence, self-efficacy, and intrinsic interest through proximál self-motivation. Journal of Personality and Social Psychology, 41(3), 586-598.

Berking, M., Holtforth, M. G., Jacobi, C., \& Krцner-Herwig, B. (2005). Empirically based guidelines for goal-finding procedures in psychotherapy: Are some goals easier to attain than others? Psychotherapy Research, 15(3), 316-324.

Berne, E. (1961). Transactional analysis in psychotherapy: A systematic individual and social psychiatry. New York: Grove Press.

Brace, K. (1992). Nonrelativist ethical standards for goal setting in psychotherapy. Ethics and Behavior, 2(1), 15-38.

Chase, W. G., \& Simon, H. A. (1973). Perception in chess. Cognitive Psychology, 4(1), 55-81.

Claessen, H. F., \& Boshuizen, H. P. A. (1985). Recall of medical information by students and doctors. Medical Education, 19, 61-67.

Cormier, S., \& Hackney, H. (2015). Kontseptualizatsiya problem i postanovka tseley [The conceptualization of problems and goal setting]. Zhurnal Prakticheskoj Psihologii i Psihoanaliza, 4. Retrieved from http://psyjournal.ru/drupal_journal/articles/konceptualizaciya-problem-i-postanovkaceley?ID=3869 (in Russian) (Transl. of: Cormier, S., \& Hackney, H. (1987). Counseling strategies and interventions. Englewood Cliffs, NJ: Prentice-Hall.) 
Doig, E., Fleming, J., Cornwell, P. L., \& Kuipers P. (2009). Qualitative exploration of a client-centered, goal-directed approach to community-based occupational therapy for adults with traumatic brain injury. American Journal of Occupational Therapy, 63(5), 559-568.

Doran, G. T. (1981). There's a S.M.A.R.T. way to write management's goals and objectives. Management Review, AMA FORUM, 70(11), 35-36.

Dörner, D. (1997). Logika neudachi: strategicheskoe myshlenie v slozhnyh situatsiyah [The logic of failure: strategic thinking in complex situations]. Moscow: Smysl. (in Russian) (Transl. of: Dörner, D. (1996). The logic of failure: Recognizing and avoiding error in complex situations. Cambridge, MA: Perseus Books.)

Holliday, R. C., Ballinger, C., \& Playford, E. D. (2007). Goal setting in neurological rehabilitation: patients' perspectives. Disability Rehabilitation, 29(5), 389-394.

Kolb, D. A., \& Boyatzis, R. E. (1970). Goal-setting and self-directed behavior change. Human Relations, 23(5), 439-457.

Kukushkina, Yu. A., \& Spiridonov, V. F. (2008). Critical thinking as a factor of programmers expertise. Psychology. Journal of Higher School of Economics, 1(5), 165-174. (in Russian)

LaFerriere, L., \& Calsyn, R. (1978). Goal attainment scaling: An effective treatment technique in short-term therapy. American Journal of Community Psychology, 6(3), 271-282.

Leontiev, A. N. (2008). Deyatel'nost'. Soznanie. Lichnost' [Activity. Consciousness. Personality]. Moscow: Moscow University Press. (in Russian)

Locke, E. A., \& Latham, G. P. (2002). Building a practically useful theory of goal setting and task motivation. American Psychologist, 57(9), 705-717.

Locke, E. A., \& Latham, G. P. (2006). New directions in goal-setting theory. Currently Directions in Psychological Science, 15(5), 265-268.

Long, J. R. (2001). Goal agreement and early therapeutic change. Psychotherapy, 38(2), 219-232.

Nelson-Jones, R. (2000). Teoriya i praktika konsul'tirovaniya [The theory and practice of counselling]. Saint Petersburg: Piter. (in Russian) (Transl. of: Nelson-Jones, R. (1995). Counselling and personality: theory and practice. Saint Leonards, NSW: Allen \& Unwin.)

Newell, A., \& Simon, H. A. (1972). Human problem solving. Englewood Cliffs, NJ: Prentice-Hall.

Platt, J. J., \& Spivack, G. (1975). Unidimensionality of the means-ends problem-solving procedure. Journal of Clinical Psychology, 31, 15-16.

Spiridonov, V. F. (Ed.). (2013). Kognitionaya psihologiya: fenomeny i problemy [Cognitive psychology: phenomena and problems]. Moscow: URSS. (in Russian)

Sternberg, R. G. (2003). The psychology of problem solving. New York: Cambridge University Press.

Tryon, G. S., \& Winograd, G. (2011). Goal consensus and collaboration. Psychotherapy, 48(1), 50-57.

Weiner, I. (2002). Osnovy psihoterapii [Principles of psychotherapy]. Saint Petersburg: Piter. (in Russian) (Transl. of: Weiner, I. B. (1998). Principles of psychotherapy (2nd ed.). Hoboken, NJ: John Wiley \& Sons Inc.)

Wollburg, E., \& Braukhaus, C. (2010). Goal setting in psychotherapy: The relevance of approach and avoidance goals for treatment outcome. Psychotherapy Research, 20(4), 488-494.

Yagnyuk, K. V., Golovkina, M. V., Zemtseva, I. G., Il'chenko, Zh. V., Manuhina, N. M., Abuhovskaya, L. V., Trepalina, N. Yu. (2013). Otklik na zapros klienta: variatsii terapevticheskih vmeshatel'stv [Response to the client's request: variations of therapeutic interventions]. Zhurnal Prakticheskoj Psihologii i Psihoanaliza, 2. Retrieved from http://psyjournal.ru/articles/otklik-na-zapros-klientavariacii-terapevticheskih-vmeshatelstv (in Russian)

Zimmerman, B. J., \& Kitsantas, A. (2002). Acquiring writing revision and self-regulatory skill through observation and emulation. Journal of Educational Psychology, 94(4), 660-668. 
Appendix

\section{The Participants' Questionnaire}

We appreciate your participation in our research. Please complete the form below. All of the provided information is strictly confidential and will be used for scientific purposes only.

Age Name Gender

Professional education (degree and specialty). Please note if you have more than one specialty

What kind of education did you receive in psychotherapy? When and where?

Number of years practicing as a psychologist or psychotherapist

Do you consider yourself as having a specific theoretical orientation? If so, which one (or ones)?

If you answered "yes" to the question above, please describe your understanding of the goal of the theoretic orientation or treatment approach

Do you currently receive clinical supervision?

Do you have a favorite type of client or specific issue that you prefer to work with and feel most effective in treating?

What are your favorite techniques or tools, or the ones that you use most often?

Have you ever received therapy as a client? If so, for how long? Was this a requirement of your psychology training program?

Are you aware of your therapist's theoretical orientation? If so, what was it?

Date

\section{The Case for Analysis (the Fragment)}

Client: I came here two years ago with motivation issues, and you helped me. At that time you said that you also work with people who stutter, from a psychological perspective. I would like to know more about that. What, how, and if it is helpful.

Therapist: Yes, I remember you. Tell me, please, what results would you like to achieve? What goals do you have to work toward right now?

$\mathrm{C}$ : Well, the highest goal is a complete elimination of my stuttering. However, there are also a lot of sub-goals. For example, to stop thinking about my speech all the time and to stop allowing it to affect my life so much. Other sub-goals are to stop associating my self-esteem with my speech impairment and, for example, stop thinking that I can't deal with the stuttering. In general, it would be enough for me to reduce the stuttering to the level where communication is possible. Then my speech wouldn't be the center of my life and a fundamental aspect of everything.

T: Those goals you described as connected to reducing your dependence on your speech quality, can be achieved through therapy. Whether the reduction of the dependence on the speech quality leads to changes in the speech - it's difficult to make predictions.

T: I should emphasize again that I do not provide treatment of stuttering as a speech disorder. Instead, we are going to work toward managing your emotional states and thoughts related to the stuttering. Developing those skills can lead to a relief or, at least, reduce emotional distress - I can help you with that. In regard to improved speech quality at the end of treatment, I honestly can't give you any guarantees - it's out of my area of competence. 


\section{$* * *$}

T: Imagine that we are transported into the future, 2-3 months ahead. And you've got that state you wanted - freedom to speak, independence from speech. That freedom would be reflected in some thoughts, right? You don't want to think every time "Can I do it or not?" What would you like to think instead?

C: Maybe it sounds weird, but nothing. At least based on my past experience at Center X, my head was absolutely empty then. The speech was just produced by itself, and my thoughts were busy with their own things.

C: I understand everything. I'm not new to stuttering.

\section{Questions of Structured Interviews}

What is the problem presented by the client? Describe in your own words.

What problem does the therapist work with? How did the therapist formulate the problem for him or herself?

What general goal did the therapist set?

What goal was set for this specific session described above?

Did the therapist do anything to reach an agreement on the goals with the client?

If yes, please underline those phrases of the therapist that served that goal.

What effect from the work does the therapist expect?

A) at the end of the therapy

B) at the end of this session

Did the therapist achieve what he planned for this specific session? Did he achieve the goal he had set? Please explain your answer.

Why do you think the therapist said this in this way?

Do you say this to your clients?

If not, then why not?

If yes, then why do you say this?

Were you taught to say this, at the beginning of your career?

If yes, then in which school of psychotherapy?

Would you say it the same way or differently? If differently, then what would you say?

Natalya V. Kiselnikova (Volkova) - deputy director, head of the Laboratory of Counselling Psychology and Psychotherapy, FBSSI Psychological Institute of the Russian Academy of Education, Ph.D.

Research area: psychology of personal problem solving, representation of problem, counselling psychology, psychotherapy.

E-mail: kiselnikova-nv@yandex.ru

Vladimir F. Spiridonov - head of the laboratory, Laboratory for Cognitive Research, Faculty of Psychology, Russian Presidential Academy of National Economy and Public Administration, D.Sc. Research area: problem solving, bottom-up and top-down mechanisms of insight, heuristic strategies, embodied cognition in problem solving, representation of problem.

E-mail: vfspiridonov@yandex.ru

Elena V. Lavrova - senior researcher, FBSSI Psychological Institute of the Russian Academy of Education, Ph.D.

Research area: psychotherapeutic practices, effectiveness of psychotherapy and counselling.

E-mail: may_day@list.ru 
Evgeniya A. Kuminskaya - researcher, FBSSI Psychological Institute of the Russian Academy of Education.

Research area: psychotherapy, psychotherapists' competence, psychological counselling, personal problem solving.

E-mail: j-aquarius@bk.ru

Svetlana V. Markova - associated researcher, FBSSI Psychological Institute of the Russian Academy of Education; , psychologist, Medlin Treatment Center (Atlanta, USA), Ph.D.

Research area: clinical psychology, methods and effectiveness of psychotherapy.

E-mail: clairmarkova@mail.ru

Mariya M. Danina - senior research fellow, FBSSI Psychological Institute of the Russian Academy of Education, Ph.D.

Research area: psychotherapeutic practices, effectiveness of psychotherapy and counselling research, high tech in mental health.

E-mail: mdanina@yandex.ru

\section{Разработка методики исследования целеполагания в психотерапии}

\section{Н.В. Кисельникова (Волкова) ${ }^{\text {a }}$, В.Ф. Спиридонов ${ }^{\mathrm{b}}$, Е.В. Лаврова ${ }^{\mathrm{a}}$, Е.А. Куминская ${ }^{\mathrm{a}}$, С.В. Маркова ${ }^{a}$ М.М. Данина ${ }^{a}$}

${ }^{a}$ ФГБНУ «Психологический институт Российской академии образования», 125009, Россия, Москва, ул. Моховая, д. 9, стр. 4

${ }^{b}$ Российская академия народного хозяйства и государственной службы при Президенте Российской Федерации, 119571, Россия, Москва, просп. Вернадского, д. 82-84

\section{Резюме}

Целью исследования выступала разработка метода, который позволил бы оценить различия в характеристиках постановки целей психотерапевтами с разным профессиональным стажем, а также проследить взаимосвязь между параметрами постановки целей и эффективностью психотерапии. Для этого, с опорой на методологические основы изучения профессионального мышления, используемые в психологии экспертизы, авторы определили особенности и условия постановки целей, способствующие их лучшему достижению. Основой для разработки метода послужило предположение, что анализ чужой психотерапевтической сессии с позиции эксперта должен стимулировать представления специалиста о целеполагании и выявить наиболее типичные способы постановки цели и их особенности. Авторы разработали сетку категорий для анализа записей структурированных интервью. Разработанная процедура может решать следующие задачи: 1) выявление характеристик целей, которые более или менее эффективны в контексте результатов терапии для клиента; 2) ответ на вопрос о трансформации процесса постановки целей и характеристиках сформулированных целей в связи с наращиванием профессионального опыта психотерапевта; 3) выявление особенностей репрезентации проблемы клиента среди психотерапевтов различной степени компетентности; 4) изучение особенностей постановки целей и представления проблемы клиента среди психотерапевтов разных подходов. 
Представлены результаты апробации методики на выборке терапевтов с более чем десятилетним опытом работы. Выявлены основные характеристики целевого состояния (достижимость, невключение третьих лиц, четкая формулировка, позитивность), которые, согласно предыдущим исследованиям, коррелируют с эффективным достижением психотерапевтических результатов.

Ключевые слова: целеполагание, психотерапия, консультативная психология, методика исследования.

Кисельникова (Волкова) Наталья Владимировна - зам. директора по научно-организационному развитию, заведующая лабораторией, лаборатория консультативной психологии и психотерапии, ФГБНУ «Психологический институт Российской академии образования», кандидат психологических наук, доцент

Сфера научных интересов: психология решения личностных проблем, субъективная репрезентация, консультативная психология, психотерапия.

Контакты: kiselnikova-nv@yandex.ru

Спиридонов Владимир Феликсович - заведующий лабораторией, лаборатория когнитивных исследований, факультет психологии, Российская академия народного хозяйства и государственной службы при Президенте Российской Федерации, доктор психологических наук, профессор.

Сфера научных интересов: психология решения задач и проблем, репрезентация задачи, стратегии решения, инсайт, подсказки, воплощенное познание.

Контакты: vfspiridonov@yandex.ru

Лаврова Елена Васильевна - старший научный сотрудник, ФГБНУ «Психологический институт Российской академии образования», кандидат психологических наук.

Сфера научных интересов: психотерапевтические практики, исследования эффективности психотерапии и психологическое консультирование.

Контакты: may_day@list.ru

Куминская Евгения Андреевна - научный сотрудник, ФГБНУ «Психологический институт Российской академии образования».

Сфера научных интересов: психотерапия, компетенции психотерапевтов, психологическое консультирование, решение личностных проблем.

Контакты: j-aquarius@bk.ru

Маркова Светлана Викторовна - ассоциированный научный сотрудник, ФГБНУ «Психологический институт Российской академии образования»; психолог, Лечебный центр (Атланта, США), кандидат психологических наук.

Сфера научных интересов: клиническая психология, методы и эффективность психотерапии.

Контакты: clairmarkova@mail.ru

Данина Мария Михайловна - старший научный сотрудник, ФГБНУ «Психологический институт Российской академии образования», кандидат психологических наук.

Сфера научных интересов: психотерапевтические практики, исследования эффективности психотерапии и психологическое консультирование, высокие технологии в психологической помощи.

Контакты: mdanina@yandex.ru 